\title{
FEDERAL INCOME TAX AFFECTING THE MINING AND PETROLEUM INDUSTRIES
}

\author{
JOHN G. MCDONALD, Q.C.*
}

\begin{abstract}
Mr. McDonald outlines and analyzes the tax changes in the 1972 Income Tax Act with respect to the Petroleum and Mining Industries. The major emphasis of the article has been placed on an examination of changes in regard to deduction of exploration and development expenses; the purchase and disposition (actual and deemed) of resource properties; the phasing out of percentage depletion allowances plus an explanation and evaluation of its subsequent substitute-"earned depletion" allowances; the changes in tax legislation in respect to new mines (most notably the elimination of the 36 month tax holiday); and the taxation of oil and gas drilling funds (limited partnerships). The article also provides a thorough coverage of minor tax alterations affecting these industries, for example, definitions which have been changed under the new Act; provincial tax abatements; prospectors and grubstakers; amalgamations; etc.
\end{abstract}

\section{INTRODUCTION}

Tax incentives to the extractive industries in Canada have been an established fact since the exploration tax credits granted under the Income War Tax Act, and the declared policy of Federal governments over the years recognized the need for such incentives in view of the exceptionally high risk factor associated with mineral exploration and the heavy capital costs required in the industry.

Since 1949 resource industries have been entitled to deduct oil and gas exploration and drilling expenses and mineral exploration and development expenses on a current basis, with an unlimited carryover of such costs in excess of annual income. In addition, percentage depletion has been a feature of the law since the 1930's. The basic changes introduced under the new Income Tax Act involve a phasing out of percentage depletion to oil and gas and mining operators and the substitution of "earned depletion", elimination of the 36 month tax holiday for new mines, and elimination of depletion allowances for shareholders of resource companies.

These restrictive changes are accompanied by a small step toward the allowance of exploration and development cost deductions to taxpayers not principally engaged in the resource industry, on a basis similar to that recommended to the Provincial Mines Ministers by the Province of Saskatchewan in 1958.

The overall balance of the changes made under the new Act is probably favourable to the continued stimulation of oil and gas exploration activity in Canada, but not to mining, if it is accepted that percentage depletion allowances (already reduced in the United States) are not an effective incentive.

\section{DEFINITIONS}

Oil and gas and mineral deductions allowed under old s. $83 \mathrm{~A}^{1}$ are now assembled in $\mathbf{s .} 66$ of the Act. ${ }^{2}$ The definitions are set out in s. 66(15).

\footnotetext{
- Barrister and Solicitor, McDonald and Hayden, Vancouver, British Columbia.

1 Income Tax Act, R.S.C. 1952, c. 148.

2 Income Tax Act, S.C. 1970-71.72, c. 63.
} 
Canadian exploration and development expenses are defined by $\mathbf{s}$. 66(15)(b) as drilling or exploration expenses, including general geological or geophysical expenses, incurred after 1971, in respect of exploring or drilling for petroleum or natural gas in Canada, and any prospecting, exploration or development expense incurred after 1971 in searching for minerals in Canada. The terms also include the cost to the taxpayer of Canadian resource properties, which are defined by s. 66(15) (c) as any right, licence or privilege to explore for, drill for or take petroleum, natural gas or other related hydrocarbons in Canada, or to prospect, explore, drill or mine for, minerals in a mineral resource in Canada. The term "mineral resource" is separately defined by s. 248(1). A Canadian resource property also includes any oil or gas well situated in Canada, any rental or royalty based on production from an oil or gas well or mineral resource situated in Canada, any real property situated in Canada the principal value of which depends upon its mineral resource content, and any right to or interest in any of the above property interests.

The mineral resource definition of s. 248(1) was expanded by the 1972 Budget to include oil sands deposits, oil shale deposits, and deposits of halite from which halite is extracted by operating a brine well, but this amendment does not apply to acquisitions or dispositions of such deposits prior to May 9, 1972.

Canadian exploration and development expenses also include a taxpayer's share of such expenses incurred after 1971 by any association, partnership or syndicate of which he was a member at the end of the fiscal period during which the expenses were incurred, and in the case of a principal-business corporation, the consideration paid by the corporation for any share (or any interest in or right to a share) received in consideration for an undertaking to incur, after 1971, the cost of drilling or exploration services in the oil and gas industry, the cost of prospecting, exploration or development services in searching for minerals in Canada, or the cost of acquiring a Canadian resource property. Shares acquired by a principal-business corporation in consideration for cost contributions in connection with drilling or exploration, or prospecting, exploration or development services will normally have a nil adjusted cost base for capital gains purposes in view of the provisions of $8.53(2)(e)$.

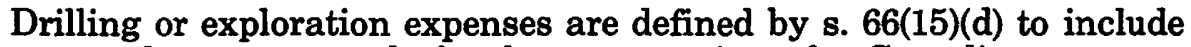
any annual payment made for the preservation of a Canadian resource property, a foreign resource property, and certain oil and gas rights described in s. 59(1)(c). The wording of this definition was, under the old law, intended to cover annual delay rentals payable under the terms of freehold leases but is now extended to cover "preservation payments" referable to mineral resource properties. The term "drilling or exploration expense" also includes, as under old s. 83A(8c), the cost of drilling or converting a well for the disposal of waste liquids, drilling a water or gas injection well, and drilling or converting a secondary recovery well.

The definition of foreign exploration and development expenses is the same as the definition of Canadian exploration and development expenses, except that the drilling, exploration, prospecting and development work must be outside Canada, and the definition does not include drilling, exploration, prospecting or development services costs incurred in consideration for stock.

Canadian resource companies operating abroad through subsidiaries 
or affiliates are still unable to deduct exploration and development expenses (or their indirect share of such expenses). The government has the question of expenses incurred by sudsidiaries "under study", but no mention was made in the May 8, 1972, budget of expenses incurred by foreign affiliates. This is a serious omission for Canadian resource companies forced to operate abroad, by foreign law, with a "less than $50 \%$ " interest in a foreign affiliate.

A "principal-business corporation" is defined by s. 66(15)(h) in the same terms as old s. $83 \mathrm{~A}(3 \mathrm{~b})$.

The definitions affecting joint-exploration corporations are found in 8. 66(15)(a),(g) and (i). There is no change in substance from the provisions of old s. $83 \mathrm{~A}(3 \mathrm{e})$. Where the shareholder corporation of a jointexploration corporation receives property as consideration for any payment made to the joint-exploration corporation in respect of Canadian exploration and development expenses, the adjusted cost base for capital gain computation purposes of the property received must be reduced under s. $53(2)(f)$ by an amount equal to the payments to the joint-exploration corporation.

\section{EXPLORATION AND DEVELOPMENT ("E \& D") EXPENSES}

As under s. 83A of the old law, s. 66 of the Act permits the deduction of Canadian E \& D expenses by principal-business corporations to the extent of income for a taxation year (before depletion deductions) with an unlimited carryover of unused deductions. Under s. 66(2) of the Act, "special product corporations" described as corporations whose principal-business is production or marketing of sodium chloride or potash or whose business includes manufacturing products the manufacturing of which involves processing sodium chloride or potash, are entitled to deduct E \& D expenses incurred "in the year" in respect of exploring or drilling for halite or sylvite in computing income for the taxation year. There does not appear to be any allowable carryover of undeducted expenses incurred by such special corporations.

The first important new allowance under the Act is found in s. 66(3), which permits individuals and corporations other than principal-business corporations to deduct, in computing income from all sources in a taxation year, the greater of $20 \%$ of the aggregate of the taxpayer's Canadian E \& D expenses incurred before the end of the taxation year to the extent that they were not deductible in computing income for the previous taxation year, and the aggregate of the taxpayer's income for the taxation year from operating an oil and gas well in Canada, from royalties in respect of an oil or gas well in Canada, income from operating a mine in Canada, royalties from a mine in Canada, and the proceeds of disposition of Canadian resource properties. The deduction allowed under s. 66(3) in a particular taxation year cannot include any amount deductible under the ITAR's.

The precedent for this allowance of $\mathrm{E} \& \mathrm{D}$ expenses, as deductions in computing income for taxpayers not normally engaged in the oil and gas and mining industries, is American. U.S. taxpayers have been entitled for many years to deduct intangible drilling and exploration expenses incurred in oil and gas exploration and production ventures against income from all sources. The new deduction in Canada under s. 66(3) is a step in the right direction toward encouraging Canadians to participate 
in mineral exploration-and therefore in the ownership of Canadian mineral resources-but it must be said that it does not yet go far enough to put Canadians on a competitive basis with United States taxpayers who invest in Canadian mineral ventures on a direct basis. This is particularly true in the petroleum industry, where oil and gas fund investments are becoming common. It may reasonably be expected that in the course of gradual amendment, the Act will be changed to allow all taxpayers to deduct E \& D expenses to the same extent as taxpayers engaged in other forms of commercial activity are permitted to deduct business expenditures. This opinion is reasonable in view of the provisions in the Act (discussed infra) under which the proceeds of disposition of oil and gas rights and royalties and mineral rights and royalties received by any individual or non-principal business corporation are includible in income and taxed at ordinary income tax rates. It is therefore inequitable that E \& D expenses, which include the costs of acquiring Canadian resource properties, are presently deductible only to the extent of the greater of the taxpayer's mineral production income or $20 \%$ of the taxpayer's undeducted E \& D expenses.

The provisions of s.66(3) of the Act may be illustrated by the following example applicable to an individual or non-principal business corporation:

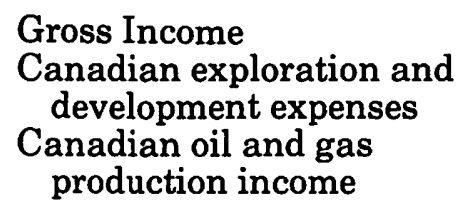

$\begin{array}{cr}\text { Year 1 } & \text { Year 2 } \\ \$ 100,000 & \$ 50,000 \\ 40,000 & 20,000 \\ 10,000 & 5,000\end{array}$

In year 1 the corporation will deduct $\$ 10,000$ of its Canadian exploration and development expenses, because its Canadian oil and gas production income of $\$ 10,000$ is greater than $20 \%$ of $\$ 40,000$ (i.e., $\$ 8,000$ ). Thus after year 1 the corporation has a Canadian exploration and development expense carryover of $\$ 30,000$. In year 2 the corporation will deduct $20 \%$ of its aggregate Canadian exploration and development expenses of $\$ 50,000$ (i.e., $\$ 10,000$ ), because it has Canadian oil and gas production income of only $\$ 5,000$ in the year.

Foreign E \& D expenses also qualify for more similar but more restrictive treatment under s. 66(4) of the Act. Individuals and all corporations may deduct foreign $E \& D$ expenses to the extent of the greater of $10 \%$ of such expenses and the aggregate of the taxpayer's income from an oil and gas well or mine operated outside Canada, oil and gas or mineral royalties from foreign sources, and from the proceeds of disposition of foreign resource properties.

The reason for the $50 \%$ differential between the $20 \%$ Canadian and $10 \%$ foreign general income deductions was probably introduced to produce the same after-tax effect as the deduction of an allowable capital loss by a Canadian taxpayer (50\% of which is deductible) upon the sale or disposition of shares of the capital stock of a subsidiary incorporated to explore for foreign resource properties. Canadian taxpayers who are concerned to avoid the consequences of this technical perfection in the Act should refer to s. 66(5), which provides that s. 66(3) and (4) (discussed supra) and s. 59 and s. 64 (old s. 83A(5ba) and the deferred revenue reserve provision (discussed in S. 104 infra) do not apply to taxpayers other than principal-business corporations whose business includes 
trading or dealing in rights, licences, or privileges to explore for, drill for or take minerals, petroleum, natural gas or other related hydrocarbons. S. $66(5)$ is derived from old s. $83 \mathrm{~A}(5 \mathrm{f})$. It therefore follows that taxpayers (other than principal-business corporations) may qualify for full deduction of foreign mineral exploration losses if they are so organized as to fall within s. 66(5) of the Act.

The application of s. 66(4) may be illustrated by the following assumptions:

\section{Gross Income}

Foreign exploration and development expenses

Foreign oil and gas production income
Year 1

$\$ 100,000$

40,000

10,000
Year 2

$\$ 50,000$

30,000

5,000

In year 1 the taxpayer will deduct $\$ 10,000$ of its foreign exploration and development expenses, because its foreign oil and gas production income of $\$ 10,000$ is greater than $10 \%$ of $\$ 40,000$ (i.e., $\$ 4,000$ ). Thus after year 1 the taxpayer has a foreign exploration and development expense carryover of $\$ 30,000$. In year 2 the taxpayer will deduct $10 \%$ of its aggregate foreign exploration and development expenses of $\$ 60,000$ (i.e., $\$ 6,000$ ), because it has foreign oil and gas production income of only $\$ 5,000$ in the year.

\section{SUCCESSOR CORPORATIONS (CANADIAN "E \& D" EXPENSES)}

S. 66(6) and (7) of the Act retain the basic provisions of old $\mathrm{s}$. $83 \mathrm{~A}(8 \mathrm{a})$ and (8d), except that all or substantially all of the property of the predecessor corporation used by it in carrying on in Canada its principal business must be acquired by the successor corporation at any time after 1971. ITAR ss. 29(25) and (29) deal with property acquisitions prior to 1972 as under the current Act.

Dealing with the foreign $\mathrm{E} \& \mathrm{D}$ expenses of successor corporations, s. 66(8) and (9) of the Act provide that where, after 1971, a successor corporation or a second successor corporation has acquired all or substantially all of the property of the predecessor corporation used by it in carrying on outside Canada its principal business, the successor corporation may deduct the aggregate of the undeducted foreign $E$ \& D expenses of the predecessor corporation to the extent of income attributable to the production of oil and gas or minerals from wells or mines situated on properties of the predecessor located outside Canada. The provisions of these sections thus add foreign $E \& D$ expenses to the class of expenses deductible by successor corporations and would appear to permit principal-business corporations to segregate $\mathrm{E} \& \mathrm{D}$ expenses into Canadian and foreign categories and to dispose of all or substantially all of Canadian resource properties to one corporation, and all or substantially' all of foreign resource properties to another corporation. This means that there may now be one predecessor to two successor corporations dealing with Canadian and foreign resource properties as part of their principal business.

An interesting addition to the rules affecting successor corporations entitled to deduct E \& D expenses under s. 66(6), (7), (8) and (9) of the Act after acquisition of all or substantially all of the property of a predecessor corporation (as under old s. $83 \mathrm{~A}(8 \mathrm{a}),(8 \mathrm{~d})$ ) is the "stop loss" provision of s. 66(11) of the Act, which is marginally noted as 
"control change". The new rule is that where control of a corporation has changed after termination of active business, E \& D expenses normally qualified for carryover for deduction in subsequent taxation years are no longer deductible. This change in the law is based upon old s. 82(13) and is intended to deny the deduction of E \& D expenses in circumstances such as those now under consideration by the Courts. ${ }^{3}$

\section{PURCHASE AND SALE OF RESOURCE PROPERTIES}

The new Act retains the basic provisions dealing with the purchase and sale of Canadian oil and gas rights, but extends this treatment to the cost of acquiring and the proceeds of disposition of foreign oil or gas rights, Canadian and foreign mineral rights, and to Canadian and foreign oil or gas and mineral royalty interests. Briefly, the cost of acquiring a "Canadian resource property" or a "foreign resource property" is a Canadian or foreign exploration and development expense, respectively, of the purchaser, and the proceeds of disposition of a "Canadian resource property" or a "foreign resource property" is includible in the income of the vendor.

Under old s. $83 \mathrm{~A}(5 \mathrm{a})$ an amount paid in respect of the acquisition of a Canadian oil or gas right was deemed to be a drilling and exploration expense, but under s. 66(14)(b)(iii) and (e)(iii) it is the cost of acquiring a Canadian or foreign resource property, respectively, that is deductible as a Canadian or foreign exploration and development expense.

\section{Canadian Resource Properties}

Old s. $83 \mathrm{~A}(5 \mathrm{a})$ which permitted an individual, corporation, or association, partnership or syndicate formed for the purpose of exploring or drilling for petroleum or natural gas to deduct an amount paid after April 10,1962, to acquire Canadian oil or gas rights as an exploration and development expense, is continued for amounts paid before 1972 in respect of such acquisitions under ITAR s. 29(14). The cost to a taxpayer of acquiring any Canadian resource property is treated by $\mathbf{s}$. 66(15)(b)(iii) as a Canadian E \& D expense, and is deductible by the taxpayer according to his status, discussed in s. 102 above. A Canadian resource property is defined by $\mathrm{s}$. $66(15)(\mathrm{c})$ as any right, licence or privilege to explore for, drill for or take oil, gas or minerals in Canada; any oil or gas well and mineral property situated in Canada; and any rental or royalty derived therefrom.

While the cost of acquiring Canadian mining properties and Canadian royalty interests after 1971 may be fully deductible in the year of acquisition, depending on the status of the purchaser, amounts received for the disposition of such properties and interests held prior to 1972 are subject to a special transitional rule (discussed infra).

\section{Foreign Resource Properties}

The cost of acquiring any foreign resource property is deductible under s. 66(15)(e)(iii) as a foreign exploration and development expense. A foreign resource property is considered to be the same as a Canadian resource property, except that the resource property must be located outside Canada. Therefore, the cost of acquiring a foreign resource property is deductible by a taxpayer according to the rules relating to the deduction of foreign exploration and development expenses.

\footnotetext{
${ }^{3}$ Gustauson Drilling (1964) Ltd. v. M.N.R. 70 D.T.C. 1736; 72 D.T.C. 6068 (Appeal Pending).
} 
3. Disposition of Canadian and Foreign Resource Properties

With the exception of Canadian oil or gas rights acquired before April 11, 1962, and disposed of before November 9, 1962, the old Act required the proceeds of disposition of such rights to be included in computing the income of principal-business corporations and associations, partnerships or syndicates formed for the purpose of exploring or drilling for petroleum or natural gas. Similarly, individuals and nonprincipal business corporations were taxable on the proceeds of disposition of Canadian oil or gas rights which were acquired after April 10, 1962. ITAR ss. 29(16)-(19) continue this treatment for amounts received in the 1972 and subsequent taxation years in respect of the disposition of oil or gas rights acquired before 1972 .

The general rules relating to the tax treatment of amounts receivable as consideration for the disposition of Canadian and foreign resource properties are found in s. 59. Generally, subject to specific exceptions, any amount receivable upon the disposition of a Canadian or foreign resource property is includible in income of the vendor in the year of disposition.

Any amount receivable by a taxpayer as consideration for the disposition of any right, licence or privilege described in s. 83A(5a) of the old Act (Canadian oil and gas), that was acquired by the taxpayer before 1972, must first be included in the taxpayer's income for the year, notwithstanding that the amount or any part thereof may not be received until a subsequent taxation year. However, s. 64 (discussed infra) permits the taxpayer to establish a reserve in respect of the amount receivable by the taxpayer as consideration for the disposition which is not receivable until a subsequent year.

The general rule is that the amount receivable by a taxpayer as consideration for the disposition of a Canadian resource property or a foreign resource property shall be included in computing his income for the year of disposition, notwithstanding that the amount or any part thereof may not be received until a subsequent taxation year. Where a taxpayer, after 1971, disposes of any of the following property:

- a foreign resource property;

- any right, licence or privilege to prospect, explore, drill, or mine for, minerals in a mineral resource in Canada;

- any rental or royalty computed by reference to the amount or value of production from an oil or gas well, or a mineral resource situated in Canada;

- any real property situated in Canada the principal value of which depends upon its mineral resource content; or

- any right to or interest in any of the above described property;

and such property was owned by the taxpayer on December 31,1971 , the "relevant percentage" of the amount receivable by the taxpayer as consideration for the disposition of the property shall be included in computing his income for his taxation year in which the disposition was made, notwithstanding that the amount or any part thereof may not be received until a subsequent taxation year. The "relevant percentage" of any amount receivable as consideration for the disposition of property is defined by s. $59(4)$ as being $60 \%$ plus the percentage (not exceeding $40 \%$ ) obtained when $5 \%$ is multiplied by the number of full calendar years in the period commencing at the end of 1972 and ending with the 
end of the calendar year in which the disposition was made. This special transitional rule relating to the disposition of a "Canadian resource property", other than any right, licence or privilege described in s. 83A (5a) of the old Act or a "foreign resource property", means that the proceeds of disposition of mining properties and mineral or oil and gas royalties will be taxable to the extent of $60 \%$ if sold in $1972,65 \%$ if sold in the second year and so on until the ninth and subsequent years (1980) when all of the proceeds will be included in income. However, as noted above, the cost of acquiring Canadian and foreign resource properties which are subject to the special transitional rule described in s. 59(3) are fully deductible by the purchaser in the year of acquisition, depending upon the extent to which the purchaser may deduct his Canadian or foreign exploration and development expenses under s. 66 .

S. $59(3)(d)$ contains a special rule relating to the purchase and sale of a resource property when the parties are not dealing with each other at arm's length. The rule is that with respect to the sale after 1971 of a Canadian resource property, other than any right, licence or privilege described in s. $83 \mathrm{~A}(5 \mathrm{a})$ of the old Act, or a foreign resource property, owned by the purchaser on December 31,1971, the cost to the purchaser shall be the same as the amount (i.e., the "relevant percentage") included in the income of the vendor, instead of the amount receivable which would be the acquisition cost to the pruchaser dealing at arm's length. When the purchaser subsequently disposes of the property or any right or interest therein, the amount receivable by the purchaser as consideration for the disposition is the "relevant percentage" of the amount receivable by the purchaser as consideration therefor. Thus when the purchaser subsequently disposes of the property he is treated as if he owned the property on December $31,1971$.

S. 66(5) states that the above rules relating to the purchase and sale of resource properties do not apply to a taxpayer (other than a principalbusiness corporation) whose business includes trading or dealing in rights, licences or privileges to explore for, drill for or take minerals, petroleum, natural gas or other related hydrocarbons.

\section{Deferred Revenue Reserve Provision}

A taxpayer is permitted by s. 64 to deduct a reserve equal to the unpaid balance of the consideration receivable in respect of the disposition of a Canadian or foreign resource property. The provisions of s. 64 are similar to those contained in s. $85 \mathrm{~B}(1)(\mathrm{da})$ and $\mathrm{s} .85 \mathrm{~B}(6 \mathrm{c})$ of the old Act. The combined effect of s. 59(2) and s. 64(1), where the consideration for the disposition of a resource property is not receivable until subsequent taxation years, and the amount of the consideration is included in the vendor's income for the current year or a previous year, is that if after the total amount deducted in year 1 has been returned to income under s. $59(2)$ in year 2 , a deferred receivable still exists for year 3 and a repeat deduction may be made in year 2 to the extent of the deferral. For example, if a taxpayer disposes of a Canadian resource property for $\$ 10,000$ payable in equal instalments over a 5-year period, $\$ 8,000$ may be deducted as a reserve in year 1 (the year of disposition), under s. $64(1) . \$ 8,000$ is returned to income in year 2 but $\$ 6,000$ is re-deducted in respect of the unpaid balance due in years $3-5$, and so on through year 4 , with a taxable balance of $\$ 2,000$ in year 5 . Therefore, if a taxpayer claims the full reserve permitted by $\mathrm{s} .64$, he is only required 
to include in income in any year over the term of the receivable the amount of cash received annually.

If a taxpayer claiming deductions under s. 64(1), at any time in the year or in the immediately following year ceases to be a resident of Canada, or becomes exempt from tax, or if a non-resident, ceases to carry on business in Canada, s. 64(2) denies any deduction in the year in which any such event occurs and in the immediately preceding taxation year.

When a resource property is sold prior to 1980 , which is subject to the "relevant percentage" requirement, it is not clear how the amount receivable will be allocated between exempt income and taxable income in computing the deferred revenue reserve deduction. Presumably it would be calculated on a proportionate basis over the term of the receivable and allocated accordingly.

\section{Contributions to Capital}

Under the old Act the Department of National Revenue permitted the contribution of oil and gas rights to a company for no consideration by way of contribution to capital. Such a contribution was considered not to be subject to tax under s. 137(2) of the old Act (new s. 245(2)) as a benefit conferred upon the company and not taxable under the provisions of s. $83 \mathrm{~A}(5 \mathrm{ba})$ of the old Act. This treatment of contributions of oil and gas rights for no consideration was based upon $\mathrm{s}$. 118(2) of the Canada Corporation Act.

The new Act makes no allowance for non-taxable contributions of resource properties by way of gift. Where a taxpayer-individual or corporate-has disposed of anything to a person with whom he was not dealing at arm's length for no consideration or for proceeds less than the fair market value at the time of disposition, or to any person by way of gift inter vivos, s. 69(1)(b) provides that the taxpayer is deemed to have received proceeds of disposition equal to the fair market value. Additionally, s. 69(1)(c) provides that where a taxpayer has acquired a property by way of gift he is deemed to have acquired the property at its fair market value at the time of acquisition.

\section{DEPLETION ALLOWANCES}

Under the old Act a taxpayer could deduct in computing income for a taxation year such amount as an allowance in respect of any oil or gas well or mine, if any, as is allowed to the taxpayer by regulation. Parts XII and XIII of the old Regulations set forth the deductions permitted in respect of depletion allowances for operators, non-operators and shareholders. The Government concluded that the old system of depletion allowances was both inefficient and unfair. Instead of the old system of automatic percentage depletion allowances, the Government has introduced an "earned depletion" system, which will limit depletion allowances after 1976 to one-third of consolidated net income and to one-third of "eligible expenditures" incurred after November 7, 1969. The earned depletion system will permit depletion which has been earned but unclaimed to be carried forward indefinitely in determining future depletion deductions.

The shareholders' depletion allowance will be withdrawn in respect of dividends received after 1971.

S. 65 of the Act provides that a taxpayer may deduct in computing in- 
come for a taxation year an allowance in respect of an oil or gas well or a mineral resource, if any, as is allowed by regulation. This is the new depletion enabling provision.

\section{Earned Depletion}

On July 6, 1971, the Department of Finance released a paper outlining proposed regulations to apply to the mining and petroleum industries. The paper stated that eligible expenditures incurred after November 7, 1969 , will earn depletion at the rate of $\$ 1$ of depletion for every $\$ 3$ of eligible expenditure, and that eligible expenditures will include the following:

(a) Canadian exploration and development expenses in the mining and petroleum industries, except for:

(i) the acquisition cost of Canadian resource properties;

(ii) costs relating to the provision of "social capital" facilitieswhich include houses, schools, hospitals, sidewalks, roads, stores, sewage disposal plants, airports, docks and similar property (other than a railroad not situated on the mine property) acquired to establish community and transportation facilities necessary for the operation of the new mine;

(iii) exploration and development expenses in the vicinity of a mine after it came into production; and

(iv) capitalized interest deemed to be included therein by virtue of s. 21(2)(b);

(b) the cost of new depreciable assets acquired for a new mine or a major expansion of an existing mine which are eligible for accelerated capital cost allowance, except "social capital";

(c) the cost of new buildings and machinery used to process ore from Canadian mineral resources beyond the stage to which they were previously processed in Canada, up to but not beyond the prime metal stage or its equivalent, except that "social capital" and off-site airports and docks that do not qualify in respect of a major expansion of a mine. A major expansion of an existing mine was defined as involving at least $25 \%$ increase in milling capacity.

Expenditures in connection with new facilities located in Canada to process mineral ores to the prime metal stage or its equivalent which earn depletion, were limited to situations where the processing would otherwise be done outside Canada and where the processing facility is an integral part of a new mine or a major expansion of an existing mine.

Effective May 9, 1972, two of the foregoing limitations were removed. The Budget statement of May 8, 1972, extended the class of expenditures which earn depletion to all equipment acquired after May 8, 1972, for the purpose of processing in Canada mineral ores after extraction and up to the prime metal stage. This will include all processing, whether or not related to a new mine or a major expansion, as well as custom processing. S. 16 of the Ways and Means Motion tabled with the Budget deals with custom processing and the allowances for other equipment will be provided by Regulation.

In addition, the Budget statement announced that income from such processing operations will be depletable and will qualify for the $15 \%$ provincial tax abatement.

Earned depletion will become deductible in 1977 and subsequent taxation years at a maximum annual rate equal to $33 \% \%$ of 
(a) production profits for the taxation year as defined in paragraph 1201(2)(a) of the old Regulations, plus royalties from Canadian resources not operated by the taxpayer,

minus

(b) deductions as provided by subsections 1201(4) and 1201(a) of the present Regulations. The maximum annual rate of claiming earned depletion will also apply to Canadian coal and gold production, and to royalty income received from Canadian resources by non-operators.

The July 6, 1971, Finance Paper also stated that where there has been a statutory amalgamation of mining or petroleum corporations (presumably an amalgamation as defined by s. 87(1)), or where a principalbusiness corporation has acquired all or substantially all of the property of another principal-business corporation used by it in carrying on its principal-business in Canada, earned depletion of an amalgamating or a predecessor corporation which has not been absorbed against its production income may be assumed by the amalgamated or successor corporation to be claimed against production income from the properties acquired from the amalgamating or predecessor corporation.

\section{Non-Operators' Depletion}

Under the old Regulations a non-operator was entitled to a percentage depletion deduction of $25 \%$ of gross royalties or rentals received from all oil and/or gas wells in which he had an interest. This automatic depletion allowance will be extended until the end of 1976, but after 1976 the non-operator's $25 \%$ depletion allowance will be repealed. Royalty or rental income received after 1976 will be classified as production income and will be eligible for the $33 \% \%$ earned depletion deduction.

As pointed out above, the cost of acquiring a Canadian resource property, which includes any rental or royalty in connection with a mineral resource or oil or gas well situated in Canada, is not an includible expenditure in computing earned depletion. However, because the cost of acquiring any Canadian resource property (which includes any rental or royalty interest) after 1971 is deductible as a Canadian exploration and development expense and because the earned depletion system does not apply to non-operators until 1976, the purchaser of a rental or royalty interest after 1971 may deduct the cost thereof and will be entitled to the non-operator's automatic $25 \%$ depletion allowance until 1976.

After 1976 it is clear that non-operators who do not incur expenditures which earn depletion will be subject to a significant increase in the tax payable in respect of rental and royalty income.

\section{Shareholders' Depletion}

Under Part XIII of the old Regulations shareholders of a corporation resident in Canada were permitted to deduct between $10 \%$, $15 \%$ or $20 \%$ of ordinary dividends received where the mineral profits of the corporation exceeded $25 \%, 50 \%$ and $75 \%$ (respectively) of the corporation's total income. The July 6,1971, Finance Paper confirms previous official statements that Part XIII of the old Regulations will be repealed in respect of dividends received after 1971 . 
The Government's stated reason for withdrawing the shareholders' depletion allowance is that the wasting nature of mining and petroleum properties (and the fact that each dividend received by a shareholder is partly a return of capital) is more accurately recognized by the deduction granted for one-half of capital losses. This reasoning is unsound because it cannot be assumed that a new company is incorporated to develop every new property, and that every shareholder realizes aggregate capital gains at least equal to his capital losses accruing because of depletion.

\section{NEW MINES-ACCELERATED CAPITAL COST ALLOWANCE}

Under s. 83(5) of the old Act profits derived from the operation of a new mine for a period of three years after the new mine commenced production in reasonable commercial properties were exempt from Canadian income tax. This "3-year tax holiday" will be withdrawn on December 31, 1973, (ITAR s. 28(1)) and thereafter an accelerated capital cost allowance system will replace it.

The 3-year tax exempt period for new mines will apply to mines reaching production in reasonable commercial quantities before November 7,1969 , which will be excluded from the accelerated capital cost allowance provisions. New mines which came into production in reasonable commercial quantities after November 7, 1969, but before December 31,1973 , will be entitled to choose the incentive they wish to adopt. If a taxpayer elects to claim exemption of the income from a new mine that is earned prior to January 1,1974 , he may not also claim accelerated capital cost allowance on eligible capital equipment and facilities relating to the new mine unless he reduces the book value of those assets by the full amount of the exempt income. Taxpayers not electing to adopt the fast write-off will not be obliged to reduce the book value eligible capital equipment and facilities relating to a new mine by the amount of exempt profits but the annual capital cost allowance relating to those assets deductible after 1973 will be limited to normal depreciation.

The Finance Paper, dated July 6, 1971, contains an outline of proposed regulations in connection with the accelerated capital cost allowance which will be available in respect of specified depreciable assets related to a new mine or a major expansion of an existing mine:

[F]or a new mine, the accelerated allowance will apply to the following types of new depreciable assets which were acquired before the mine came into production and for the purpose of gaining or producing income from the mine, including income from the processing of mineral ores up to the prime metal stage or its equivalent:

(1) a building (except an office building that is not situated on the mine property);

(2) mining machinery and equipment;

(3) electrical plant that would otherwise be included in class 10 of Schedule B by virtue of subsection 1102(9) of the Income Tax Regulations;

(4) houses, schools, hospitals, sidewalks, roads, sewers, sewage disposal plants, airports, docks, and similar property (other than a railroad not situated on the mine property) acquired to establish 
community and transportation facilities necessary for the operation of the mine.

Depreciable property of the type listed above in (1), (2) and (3) will also qualify for the accelerated capital cost allowance where it is acquired in the course of the major expansion of an existing mine and before the commencement of production at the higher level of capacity. For this purpose a major expansion will be considered to have taken place if the productive capacity of the mine mill is increased by at least $25 \%$.

Expenditures incurred after November 7, 1969, on the above types of depreciable assets, and related to a new mine which came into production after that date or to a major expansion of an existing mine which took place after that date, will qualify for the accelerated allowance. The cost of the qualifying assets will be included in a special class for each mine, rather than in their usual classes. In respect of such a special class the taxpayer may claim the full amount of the undepreciated capital cost up to the amount of the income from the mine, and in any event may claim at least $30 \%$ of the undepreciated balance. Where the expenditures were incurred prior to the 1972 taxation year, the amount which might reasonably be considered to be the undepreciated capital cost of such expenditures can be transferred from their present classes to the special class for each mine at the commencement of the 1972 taxation year. If the taxpayer elects to claim exemption of the income of a new mine that is earned prior to 1974 , he cannot also claim accelerated capital cost allowance on expenditures related to the mine unless he reduces the depreciable cost by the amount of the exempt income.

\section{PROVINCIAL TAX ABATEMENT}

Under former law a corporation could deduct from its federal income tax payable for a taxation year an amount equal to $10 \%$ of its taxable income earned in a province (other than the Northwest Territories or the Yukon Territory) (s. 40(1)). Additionally, a corporation could deduct in computing its income an allowance in respect of provincial mining $\operatorname{taxes}(\mathrm{s} .11(1)(\mathrm{p}))$.

S. 124(1) continues the treatment of the provincial corporate tax abatement until December 31, 1976. After January 1, 1977, the provincial corporate tax abatement will be increased to $25 \%$ of mining production profits and this increased abatement will apply as well in the Northwest Territories and the Yukon. After December 31, 1976, provincial mining taxes will no longer be deductible in computing income.

S. 124(2) provides that for a taxation year ending after December 31, 1976, the provincial corporate tax abatement will be increased to $15 \%$ of the lesser of:

(a) the corporation's "taxable production profits" from "mineral resources" earned in the year in a province; and

(b) the corporation's taxable income earned in the year in a province less the aggregate of the corporation's Canadian investment income and foreign investment income and four times the small business deduction provided for by $\mathrm{s.} 125$.

The Finance Paper provides that "taxable production profits" will be defined in the Regulations to be the amount on which the present $33 \% \%$ automatic depletion allowance is claimed under 8. 1201(2) of the old 
Regulations, less the amount of any earned depletion allowance related to these profits. For the purposes of s. 124(2) "a province" includes the Yukon and the Northwest Territories.

A "mineral resource" was initially defined in s. $248(1)$ to include a coal deposit, bituminous sands deposits, sylvite, halite, silica and gypsum. This definition of a mineral resource is basically the same as the definition of a "resource" in old Regulation s. 1201(1) except that a royalty interest and an oil or gas well is exluded. The definition was expanded in s. 26, Ways and Means Motion, 1972 Budget, with respect to property acquired or disposed of after May 8, 1972, to include oil sands deposits, oil shale deposits and deposits of halite using the brine well extraction process.

\section{PROSPECTORS AND GRUBSTAKERS}

The provisions of the old Act relating to prospectors and grubstakers (financial backers) were enacted for the purpose of providing a fiscal incentive to encourage the discovery and development of Canadian mineral resources. In 1950, the Minister of National Revenue said that underlying the technical wording of 8.83 were three objectives:

(1) to exempt the real prospector who does "the dirty work";

(2) to exempt those who had the real risk in backing the prospector; and

(3) to tax amounts where individuals or companies are merely acting as traders, promoters, or underwriters at no special risk to themselves.

Under s. $10(1)(j)$ and s. $83(2)$ of the old Act, an individual prospector who received an amount otherwise includible in computing his income was entitled to exclude it if it was:

(1) consideration for a mining property or interest therein acquired by him as a result of his efforts as a prospector either alone or with others, or

(2) consideration for shares of the capital stock of a corporation received by him for a mining property or interest therein acquired by him (as under (1)) that he had disposed of to the corporation.

The amount received by the prospector was not eligible for the exclusion if it was received by him as or on account of rent, royalty or a similar payment. Additionally, it is well settled that a prospector claiming s. 83(2) relief must establish that he acquired the mining property as a result of his prospecting, exploration or development activity and not by merely staking it. ${ }^{4}$

The Act continues to provide prospectors and grubstakers with a fiscal incentive based on the requirements of old 8 . 83 but the incentive is now deferral of tax and capital gains treatment of gain rather than exemption from tax.

S. 35 of the Act defines prospectors and grubstakers in the same terms as s. $83(1)$ (c) and s. $83(3)$ of the old Act, respectively. A prospector is still an individual who prospects or explores for minerals or develops a property for minerals and a grubstaker is a person-individual or corporation-who has under an arrangement with, or as an employer of a prospector, advanced money for, or paid part or all of the expenses of 
prospecting or exploring for minerals or of developing a property for minerals.

When a prospector or a grubstaker has disposed of a mining property or interest therein in consideration for shares of the capital stock of a corporation the following rules apply:

(1) shares in the capital stock of the corporation received by the prospector or grubstaker are not includible in computing his income in the year of receipt;

(2) the cost base of the shares received by a prospector or grubstaker, for the purposes of capital gain tax, is zero; and

(3) the cost to the corporation of the mining property or the interest therein acquired from a prospector or grubstaker is similarly zero, and the corporation is not entitled to a deduction of the cost of acquiring the mineral property or an interest therein as an exploration and development expense under s. 66 .

When the prospector or grubstaker subsequently sells the shares of the capital stock of the purchasing corporation the amount received for those shares will be subject to capital gain tax treatment.

In order for a grubstaker to be entitled to capital gain tax treatment, the following conditions of s. 35(1)(b) must be strictly complied with:

(1) the grubstaking arrangement between the grubstaker and the prospector must have been made before the prospecting work was undertaken;

(2) the grubstaker must have advanced money for, or paid part or all of, the expenses of the prospector in prospecting;

(3) the prospector must have actually performed prospecting work on the mining property prior to the acquisition of the mining property by the prospector on behalf of the grubstaker, so that it was through such prospecting efforts that the grubstaker acquired the mining property; and

(4) the consideration received by the grubstaker for the mining property was shares in the capital stock of the corporation to whom the grubstaker disposed of the mining property.

Neither s. 35 nor the ITAR's indicate what treatment will be afforded to a grubstaker who enters into an arrangement with a prospector prior to January 1, 1972, but receives the mining property after January 1, 1972. Presumably if the arrangement with the prospector was entered into prior to January 1, 1972, and the prospector commenced prospecting, exploration or development work prior to January 1, 1972, and the grubstaker receives shares of the capital stock of a corporation in consideration for the mining property prior to January 1,1972, but subsequently disposes of the shares after January 1, 1972, the provisions of $\mathbf{s}$. 83(3) of the old Act will apply because s. 35 refers to shares of the capital stock of a corporation received in a taxation year which would imply a taxation year commencing after January 1, 1972.

\section{AMALGAMATIONS}

Where there has been an amalgamation of two or more Canadian corporations after 1971 , and the amalgamation corporation is a principalbusiness corporation, ss. $66(15), 87(6)$ and (7) permit the amalgamated corporation to deduct not only the aggregate of undeducted Canadian exploration and development expenses but also the aggregate of undeducted foreign exploration and development expenses incurred by 
each amalgamating corporation, to the extent of income as may reasonably be regarded as attributable to the production of petroleum or natural gas from wells, or the production of minerals from mines, situated on property in Canada or outside Canada from which the amalgamating (predecessor) corporations had a right to take or remove minerals, petroleum or natural gas.

S. $85 \mathrm{I}(3)$ of the old Act restricted the deduction by an amalgamated corporation of undeducted Canadian drilling and exploration expenses of the amalgamating corporations to the extent of income as may reasonably be regarded as attributable to the production of petroleum or natural gas from wells, or the production of minerals from mines, situated on property in Canada of the amalgamating corporation. Where the amalgamating corporations had undeducted lease acquisition costs, which by s. $83 A(5 a)$ of the old Act were deemed to be drilling and exploration expenses, the amalgamated corporation was deemed by $851(2)(1)(a)$ to have acquired the leases under an agreement, contract or arrangement described in $83 \mathrm{~A}(5 \mathrm{a})$. Because the amalgamated corporation was deemed for the purposes of $\mathrm{S}$. $83 \mathrm{~A}$ to have acquired the leases, and by s. $83 \mathrm{~A}(5 \mathrm{a})$ the amount paid in respect of the acquisition thereof was deemed for the purposes of s. $83 \mathrm{~A}(3 \mathrm{~b})$ to be a drilling or exploration expense of the amalgamated corporation, deduction by the amalgamated corporation of undeducted lease acquisition costs of the amalgamating corporations under s. $83 \mathrm{~A}(3 \mathrm{~b})$ were not restricted by reference to production income derived from property acquired from the amalgamating corporations. (The Rulings Division of the Department of National Revenue disagrees with this opinion.)

S. $85 \mathrm{I}(2)(1 \mathrm{a})$ of the old Act disappears in the new Act with the result that, upon an amalgamation, the restricted exploration and development expense carryover of the amalgamating corporations includes the cost to the amalgamating corporations of lease acquisition costs. However, s. 87(2)(p) provides that the proceeds of disposition of lease acquisition costs included in computing the income of an amalgamating corporation under s. $83 \mathrm{~A}(5 \mathrm{ba})$ or $(5 \mathrm{c})$ of the old Act "shall be deemed to have been included in computing the income of the new amalgamated corporation for a previous year". This "deemed inclusion" is deemed to be for the purpose of computing a deduction from the income of the new corporation for a taxation year under s. 64 , so that the amalgamated corporation is, in effect, entitled to reserve deductions in respect of the proceeds of disposition receivable by an amalgamating corporation.

Under ss. $87(2)(\mathrm{gg})$ and 192 the designated surplus of amalgamating corporations in a horizontal amalgamation is continued in the amalgamated corporation. Where a controlled corporation is merged with its parent in a vertical amalgamation, a tax of $25 \%$ of the designated surplus of the controlled corporation is payable by the parent. If, as a result of an amalgamation, control of a predecessor corporation changes, its surplus will become designated as a result of the amalgamation.

Designated surplus created before the end of 1971 can be distributed to the controlling corporation subject to payment of an elective tax of $15 \%$ of the 1971 undistributed income on hand of the controlled corporation. 


\section{OIL AND GAS DRILLING FUNDS}

In the early sixties a new vehicle was developed in the United States to raise risk capital for investment in the oil and gas industry. This vehicle, which is commonly known as a "drilling fund", is a limited partnership the units of which are sold to investors in the same manner as mutual fund shares. The limited partnership form of organization is used because it provides investors with limited liability, and at the same time permits the investor to enjoy income tax benefits which would not be available through use of the corporate form. The basic tax advantage is the "flow-through" of exploration and development expenses to the participant who may deduct such expenses in computing income from all sources. In other words, oil and gas drilling funds provide "tax shelter" for individual and corporate investors.

Because drilling funds are partnerships, they are subject to both the income tax rules relating to exploration and development expenses (s. 66) and to partnerships (s.96). Notwithstanding the complexity of these rules, it would appear that drilling funds will soon become an attractive means to generate risk capital for exploration in both the oil and gas and mining industries in Canada. The principal drawback to the use of such funds in Canada is that individuals are restricted to deducting the aggregate of their Canadian exploration and development expenses to the extent of the greater of $20 \%$ of that aggregate and the total of their resource income for the taxation year, while by comparison, in the United States individuals may deduct annually the aggregate of their "intangible" exploration and development expenses incurred.

\section{Partnerships}

Under the old Act partnerships were not taxed as separate entities, but the partners were taxed on their share of the partnership income as if they personally received the income. Subdivision $j$ of the Act (ss. 96103) deals with the taxation of partnerships and their members. Under the new Act, a partnership is treated as a separate entity for the purpose of computing its taxable income, but there will be no tax payable by the partnership itself, and partners will continue to be taxed on their share of the partnership's taxable income, and be entitled to deduct their share of partnership losses.

The Act distinguishes between a "partnership" and a "Canadian partnership". S. 102 defines a Canadian partnership as "a partnership all of the members of which were, at any time in respect of which the expression is relevant, resident in Canada".

\section{Exploration and Development Expenses of Partnerships}

S. 96(1) of the Act provides that where a taxpayer is a member of a partnership, his income, net capital loss, or non-capital loss, if any, for a taxation year, or his taxable income earned in Canada for a taxation year, as the case may be, shall be computed as if the partnership were a separate person resident in Canada, and as if each income or loss of the partnership for a taxation year were computed as if no deduction were permitted by ss. $65(1)$ or 66 or the provisions of the ITAR's relating to exploration and development expenses. Ss. 65 and 66 respectively deal with depletion allowances and exploration and development expense deductions. The ITAR's apply to exploration and development 
expenses incurred prior to January 1,1972 , and are substantially the same as those in effect under the old Act.

Additionally, s. $96(1)(f)(g)$ provides that income and loss shall be computed as if the income or loss of a partnership for a taxation year from any source were the income or loss of the taxpayer from that source "to the extent of the taxpayer's share thereof".

These provisions of s. 96(1) do not mean that partners are not entitled to deduct exploration and development expenses, because s. 66(3) and (4) permit an individual or a non-principal-business corporation to deduct Canadian and foreign exploration and development expenses incurred. Canadian and foreign exploration and development expenses are defined by s. 66(15)(b) and (e), respectively, in the case of an individual or nonprincipal-business corporation, to be the taxpayer's share of the Canadian and/or foreign exploration and development expenses incurred after 1971 by any association, partnership or syndicate during its fiscal year, if at the end of that year the taxpayer was a member or partner of the firm or syndicate.

It follows that although partnership income is computed on an "entity" basis, members of an oil and gas drilling fund partnership may deduct Canadian and/or foreign exploration and development expenses in computing taxable income after attribution to them of the income or loss of the partnership of which they are members. The deduction is limited to the greater of a partner's annual income from Canadian production of oil and gas or minerals or $20 \%$ of his allocable share of Canadian exploration and development expenses incurred by the partnership. Foreign exploration and development expenses are deductible up to the greater of a partner's annual income from foreign production of oil and gas or minerals or $15 \%$ of his allocable share of such expenses. Deductions in excess of mineral production income may be taken against other income-which results in a degree of "tax shelter".

\section{Contribution of Resource Properties to a Partnership}

The basic rule under s. 97(1) of the Act is that where, after 1971, a partnership has acquired property from a taxpayer who was immediately after that time a member of the partnership, the partnership is deemed to have acquired the property at an amount equal to its fair market value at that time and the taxpayer is deemed to have disposed of the property for the same amount.

Where, after 1971, a partnership (other than a "Canadian partnership") acquires property from a "majority interest partner", who was, immediately after the acquisition, a member of the partnership, and:

(1) his share of the income of the partnership from any source for the taxation year of the partnership in which the property was acquired exceeds one-half of the income of the partnership from that source for the year, or

(2) the amount he would receive if the partnership was wound up immediately after the acquisition (otherwise than as his share of any income of the partnership) exceeds one-half of the aggregate of all such amounts that would be so paid to all persons as members of the partnership,

s. 97(3) of the Act provides that the partner's loss, if any, arising from the acquisition of the property by the partnership: 
(1) is not deductible in computing his income, net capital loss, or noncapital loss for any taxation year, and

(2) shall, where immediately before that time he was a member of the partnership, be included in computing the adjusted cost base to him of his interest in the partnership and in any other case, be included in computing the cost to him of his interest in the partnership.

S. 97(2) of the Act provides a special rule for Canadian partnerships under which, if all the partners by joint election in prescribed form agree upon the amount or value of property contributed to the partnership by a partner after 1971, the agreed amount is deemed to be the partner's proceeds of disposition and the amount for which the partnership acquired the property. If a partner receives no consideration for oil and gas or mining properties transferred to a Canadian partnership other than his interest in the partnership, the agreed amount will be included in computing the adjusted cost base to the partner of his interest in the partnership (provided that the agreed amount cannot exceed the fair market value of the properties transferred).

\section{Adjusted Cost Base of Partnership Interests}

S. 40 states that a taxpayer's gain for a taxation year from the sale or disposition of any capital property is the amount, if any, by which the proceeds of disposition exceed the adjusted cost base to the taxpayer of the property so disposed of.

A partnership interest is capital property for the purpose of the capital gain tax, and the cost base of the partnership interest is keyed to the cost of the underlying partnership assets. For the purpose of computing the taxable capital gain of a partner who disposes of his partnership interest, s. 100(2) of the Act provides that there shall be included, in addition to the amount of the gain determined under s. 40(1), the amount, if any, by which all amounts required by s. $53(2)$ to be deducted in computing the adjusted cost base to the partner exceeds the aggregate of the cost to the partner of his interest in the partnership and all amounts required by s. 53(1) to be added in computing the adjusted cost base to him of his partnership interest. Upon disposition of a partnership interest, in computing a partner's gain, exploration and drilling expenses allocated to him are treated as deductions in computing the adjusted cost base of his partnership interest. To the extent that exploration and drilling expenses incurred and allocated to a partner exceed the original cost of his partnership interest, such excess is "recaptured" as part of a taxable capital gain upon the disposition of his partnership interest.

Where, after 1971, any partnership disposes of property to a taxpayer who was, immediately before that time, a member of the partnership, s. 98(2) of the Act provides that the partnership shall be deemed to have disposed of the property at its fair market value at that time, and the taxpayer shall be deemed to have acquired the property for the same amount.

\section{Capital Gain or Loss Treatment of Non-Resident Partners}

A non-resident's taxable income earned in Canada for a taxation year includes the amount of his income for the year that would be determined under s. 3 as if the only taxable capital gains and allowable capital losses 
were taxable capital gains and allowable capital losses from dispositions of "taxable Canadian property".

Taxable Canadian property is defined by s. 115(1)(b) to include real property situated in Canada or an estate or interest therein, and a "more than 50\% interest" in a partnership. A "more than 50\% interest" in a partnership is technically defined by s. $115(1)(b)(v)$ to include a minority interest in a resource fund.

\section{Allocation of Income or Loss of a Partnership}

Most U.S. drilling funds provide for the allocation of tangible and intangible costs between the limited partners (participants) and the general partner so as to maximize the expenses which a participant may deduct in the year in which they are incurred.

Where the members of a partnership operating in Canada have agreed to share income or loss of the partnership from any source or from sources in a particular place, as the case may be, or any other amount in respect of the activity of the partnership that is relevant to the computation of the income or taxable income of any of the partners, s. 103 provides that if the principal reason for the agreement may reasonably be considered to be the reduction or postponement of the tax that might otherwise have been or become payable, the share of each partner of the partnership in the income or loss, as the case may be, is the amount that is reasonable having regard to all the circumstances (including the proportions in which the partners have agreed to share the profits and losses of the partnership from other sources or from sources in other places). The purpose of this rule is to prevent artificial or unreasonable allocation of profits or losses of a partnership to particular partners. Arm's length allocations of income and losses are not likely to be challenged under s. 103.

\section{ROLLOVERS-RESOURCE PROPERTIES}

It is regrettable that the present Government has seen fit to disentitle resource properties to rollover treatment where there is no realization of gain or loss upon the transfer of resource properties to a corporation from an individual, partnership or corporation. The exclusion is so obvious that the Government must have intended to discriminate against the resource industries in connection with tax-free rollovers.

I personally drew this problem to the attention of the Department of Finance in 1971, and the only response was amendment of $\mathrm{s} .85(2)$ to confirm the Department's intention to "lock-in" resource properties. Departmental officers have shown no tendency to consider the practical problems of the resource industries.

The combined operation of ss. 39(1), 54(b), 59(1), 69(1)(b)(iii) and 85 of the Act leads to the conclusion that Canadian and foreign resource properties can neither be contributed to the capital of a subsidiary corporation for no consideration nor transferred under any rollover provision of the Act without a deemed disposition occurring at fair market value. These consequences will impede normal commercial operations in the oil and gas and mining industries because the proceeds of disposition of resource properties are taxable as ordinary income (i.e., not capital gain income).

Furthermore, the cost of resource properties in many cases is non- 
deductible. Oil and gas rights acquired prior to April 10, 1962, have been in the non-deductible category for years, and now, in 1972 the cost of mining properties acquired prior to 1972 is also non-deductible, although the proceeds of sale or "deemed" sale are taxable.

The rollover rules relating to the contribution of property to a partnership are restricted to the contribution of property to a Canadian partnership (s. 97(2)), and there would appear to be no legitimate reason why this rollover provision should not be extended to include Canadian resource properties transferred to all partnerships. The reason for this proposal is that many joint venture transactions in the mining and oil and gas industries are carried on in partnership form and, in many cases, one or more of the partners is not resident in Canada. 